\title{
Standards, Practical Tools in Dealing with Climate Change
}

\author{
Biatna Dulbert T and Ellia Kristiningrum \\ Reseacher from National Standardization Agency of Indonesia \\ Manggala Wanabakti Building, Block IV, $4^{\text {th }}$ Floor \\ Jend. Gatot Subroto St. Senayan, Jakarta Pusat 10270 \\ Phone: +6281586254181
}

\begin{abstract}
Drastic climate change is becoming an increasingly serious threat to the survival of living beings on this planet. Various effects have been caused by climate change such as rising temperatures, floods, rising sea level, the uncertain season and other radical changes. Other than forest destruction, as well as industry and transportation use fossil fuels contributed in exacerbating climate change. Indonesia, have adopted identical to the four Green House Gases (GHG) into the SNI via reprints. As a developing country and the condition of Indonesia's forests and peatland in the tropics, it is more easy going deforestation and degradation. Indonesia is concentrated to develop standards in deforestation field based decreased functions of tropical rain forests as carbon sinks are big enough, not to mention the peatland carbon stocks that have high potential around 36 Gton $\mathrm{CO}^{2}$ from 22 million hectares only. The development of ISO standards in measurements and calculations the Greenhouse Effect, Product Recycling, Promoting Environmental good, Energy Efficiency, Consumer Aware Environmental, very useful and contribute to tackle climate change significantly with the implementation of international standards. The most important thing now is how far the destruction of nature caused by human habits that are not environmentally friendly. Increasing understanding about the scale of change needed to tackle global warming, government, business and civil society should be able to perform the necessary steps and face the need to work in partnership to address such a change. In the long term the benefits of addressing climate change will far outweigh the impact costs . But in the short term, governments, business, and civil society will be more willing to bear those costs if they know their counterparts and competitors use standards, as a practical tool in dealing with climate change.
\end{abstract}

Key word: Climate Change, Environmental, Energy

\section{Backgroud}

Drastic climate change is becoming an increasingly serious threat to the survival of living beings on this planet. Various effects have been caused by climate change such as rising temperatures, floods, rising sea altitude, the uncertain season and other radical changes. The occurrence of such things as a result of human behavior in the past in managing natural resources, economic interests and technologies that are not environmentally friendly. Management and utilization of forests without considering the functions of forests as suppliers of oxygen and carbon sinks are also to be the cause of drastic climate change. This can be seen from the reduction in forest area of the original 4110 million hectares in 1960 to 3952 million hectares in 2005 (based World Forests, FAO) means there has been damage amounting to 158 million hectares of forests within 45 years (or $4 \%$ from the previous forest area).
Earth has been hit by severe fevers of 5.8 degree Celsius rise in temperature uniformly occurred in Jakarta, Tokyo, Kathmandu, London, Johannesburg, Funafuti, Beijing, and New York. The emergence of deadly diseases such as malaria and bird flu, the condition of coastal plains that used to be turned into a shelter for fish and marine creatures sea level due to increase in 3-5 feet hit all the beaches on Earth, and various kinds of natural disasters caused by natural changes. Results of recent studies IPCC (Inter-Governmental Panel on Climate Change), was released in 2007 even showed that indeed humans are the cause of 90 percent of climate change (Http://pusper.umy.ac.id).

Other than forest destruction, as well as industry and transportation energy use, especially high oil fuel contribute in exacerbating climate change. Industry also produce gas emissions into the air and the waste discharged into rivers or inland damaging both water and land ecosystems. Mining industry 
sectors, spread almost all over the world contributed a great damage to natural ecosystems.

Currently we can not stop the ongoing climate change, what we can done is only slow the process of climate change by reducing or stopping the destruction of the environment. Climate change and other environmental challenges will be resolved only through broad ranging actions by governments, individuals, corporations and other organizations.

ISO and IEC is an international standardizing bodies in charge of setting international standards. In formulating the international standards related to climate change, ISO and IEC, working at various other international institutions such as the UNFCCC, WRI, WBCSD, IEA, WEC, UNIDO, UNEP, WMO, OECD and others. The contribution of International Standards such as ISO and IEC becomes important as a practical tool to overcome (that offer practical tools to address) of climate change in 4 (four) stages: the first with the monitoring of climate change through the measurement standards and equipment and basic techniques (eg: geomatik, meteorology). Second, by calculating the greenhouse gas emissions as well as communicate the environmental impact. The third stage is the best way of promoting the design and environmental management, for example with the widespread application of ISO 14001 by the organization.

The next step is to open markets for energy. This step is devoted to energy efficiency, renewable resources, including the establishment of programs for hydrogen, nuclear, solar, and wind technologies. In addition, other activities is a new standardization activities for solid and liquid biofuels.

\section{Standard Measurement and Calculation of the Greenhouse Effect.}

The changing climate can be caused by human activities that produce greenhouse gases. This greenhouse gas give a greenhouse effect that is trapped sunlight by greenhouse gases in the atmosphere. This is causing Earth's temperature rose gradually. Greenhouse gases consist of various types of gas, but the most dominant and dangerous gas is carbon dioxide $\left(\mathrm{CO}_{2}\right)$, that produced by burning fossil fuels for energy and transport sectors.

Steps to measure greenhouse gas emissions and communicating its environmental impact (eg ISO 14064 series for GHG accounting, verification and validation and ISO 14065 for an accreditation body that handles this activity) represents an important step in dealing with climate change.

ISO/TC 207, environmental management has been set ISO 14064 series for GHG accounting, verification and validation and ISO 14065 for the accreditation of bodies carrying out these activities. These standards contribute as an international reference in defining the calculation, verification and validation of $\mathrm{GHG}$, so that the common perception for the entire country in the world in the mapping and condition of GHG and climate change in general. This becomes very essential to remember if there is a difference GHG perspective it would be difficult to take the steps proper handling by the international community. So the role of international standards in this respect is fundamental to climate change monitoring and measuring greenhouse gases, especially supported by the standard unit of measurement, geographic information standard that is used to describe the data is very important for environmental policy making (Geographic information standards are being Used to DESCRIBE data of fundamental importance to environmental policy making) (ISO/TC 211) and metrology.

Indonesia, have adopted identical to the four Green House Gases (GHG) into the Indonesian National Standard (SNI) via republication method (reprints) consisting of ISO ISO 14064-1:2009 Greenhouse gases - Part 1: Specification with guidance at the organization level for quantification and reporting of greenhouse gas emissions and removals, SNI ISO 14064-2:2009 Greenhouse gases - Part 2: Specification with guidance at the project level for quantification, monitoring and reporting of greenhouse gas emission reductions or removal enhancements, SNI ISO 14064-3:2009 Greenhouse gases - Part 3: Specification with guidance for the validation and verification of greenhouse gas assertion, and SNI ISO 14065:2009 Greenhouse Gases - Requirements for greenhouse gas validation and verification bodies for use in accreditation or other forms of recognition.

As a developing country and the condition of Indonesia's forests and peatlands in the tropics, so the more easy going deforestation and degradation. Decreased functions of tropical rain forests as carbon sinks are big enough, not to mention the peatland carbon stocks that have high potential to reach 36 giga tonnes of carbon, to 22 million hectares (based on Tempo Daily, Friday August 28, 2009). This became the focus of the government in an effort to implement emission reduction 
commitments reached $26 \%(0.767 \mathrm{Gt})$ in 2020 was the forestry sector amounted to 0.30 Gton and Peat emissions amounted to 0.280 . So that Indonesia is compiling material for a proposed calculation of carbon from deforestation, especially in tropical forest and peat land for the proposed New Work Item Proposal deforestation standards.

\section{Product Recycling.}

In addition to international standards, there are also guidelines, such as ISO/IEC Guide 41:2003 is used to maximize the direct and indirect benefits to purchasers of goods and services by eliminating unnecessary packaging thus reducing the prices of goods and the amount of waste.

The guidelines also protect consumers from potentially harmful effects of the package or its contents and allows consumers to store goods and packaging, and to dispose or recycle them in ways that minimize their environmental impact. ISO has also established several recycling-related standards including ISO 30000, ship recycling management system, will provide support for environmental protection and improve the safety of workers. There are also ISO 14040:2000 - Principles and framework for life cycle analysis which can be used as capital in building recycling systems analysis.

Indonesia, BSN has had some SNI related to recycled products, such as the SNI 06-6671-2002 used oil management procedures using portable containers, SNI ISO IEC/TR 62235:2009 nuclear Facilitation- Instrumentation Systems and important controll to safety - Storage Systems temporary and final repository of waste and spent nuclear fuel, SNI 19-7030-2004 Specification of compost from domestic organic waste, SNI 06-3768-1995 Retreading of passenger and commercial tires, and other standards related to product recycling.

\section{Promoting Good Environmental.}

ISO 14001 is an international standard for Environmental Management System (EMS) which is currently widely used EMS in the world, with more than 6000 certification in UK and 111000 certification around the world in 138 countries. ISO 14001 is a standard key management system that specializes in the requirements for the formulation and maintenance of the EMS. Three fundamental commitment to support environmental policies for the fulfillment of the requirements of ISO 14001 is the prevention of pollution, compliance with existing laws, and continual improvement of EMS.

Environmental system management is one of practical tools are offered for dealing with climate change. Overall implementation of ISO 14001 as a way to promote the best way in the design and environmental management. Until 2006, ISO 14001 has been implemented by 130.000 companies from 140 countries around the world (7th Cusco, Peru, 10-11 August 2008), while the number of companies in Indonesia are applying 625 companies for ISO 14001 and 5 companies for ecolable. (National Acreditation Committee, 2009). Implementation of ISO 14001 provides a systematic way to identify and manage the environment and this is a liability. ISO 14001 Environmental Management System is a systematic approach to identifying environmental aspects and impacts and for the formulation of objectives and targets. To respond to these things, usually that leads to process efficiency.

Products that meet environmentally friendly requirements indicated by affixing the label. In the ISO standard there are two types of labeling, ISO 14021 Type II environmental labeling, where producers and suppliers of their own claim with the labeling on products and advertising; and ISO 14024 Type I environmental labeling, where a third party program to award labels based on multiple criteria that is free with consider the overall environmental life cycle. In this case can be harmonized eco labels in many countries including Indonesia, to minimize environmental impact throughout the product life cycle, such as the use natural resources, energy, water and chemicals.

\section{Energy Efficiency.}

Energy is fundamental in the life and part of the strategic issues in economic development. In a situation like this, there is no harm done if the starting current steps toward energy efficiency, because of double impact of energy efficiency. In addition, efficiency also provides a higher comfort. By developing market with energy-efficient technologies and renewable resources, including the establishment of programs for hydrogen, nuclear, solar and wind technologies, and standardization of new jobs for solid and liquid biofuel, and standards, is one practical tool for dealing with the changes offered climate. In the development of energy efficiency is supported by international standards 
such as ISO 13790 energy performance of buildings, ISO 21930 and others.

Programs that will come, the ISO will develop low levels of carbon technology, clean energy (lowcarbon, clean energy technologies) and industrial energy efficiency (ISO 50001) and the development of international standards through the Technical Committee as ISO/TC163 thermal performance and energy use in the built environment and ISO/TC205 - eg application of design how many ventilators, Nowhere to locate, etc.

\section{Environmentally conscious consumer.}

Along with the continued increase in demand for products and services, is expected to be emphasized environmental factors (The ever-increasing in demand for products and services is putting added pressure on the environment). Consumers should care about environmental issues, which affect the lives and health, and will contribute more to sustainable survival. The selection of products and services that are environmentally-friendly services is one of the most significant action that can be done by today's consumers.

The development of ISO standards are supported by 186 active Technical Committee, 3.000 bodies that exist and 50.000 technical expert and the cooperation of other international organizations with standard measurements and calculations the Greenhouse Effect, Product Recycling, a good environment Promotion (Promoting Environmental good), Energy Efficiency, Consumer environmentally conscious, very useful and contribute to tackling climate change is significant with the implementation of international standards.

VII. Summary.
The most important thing now is how far the destruction of nature caused by human habits that are not environmentally friendly. With an increasing understanding about the scale of change required to tackling global warming, government, business and civil society should be able to undertake the necessary steps and face the need to work in partnership to address such a change. In the long term the benefits of addressing climate change will far outweigh the costs. But in the short term, governments, business, and civil society will be more willing to bear those costs if they know their counterparts and competitors are bearing them as well. Standards, is one of the practical tools dealing with climate changes.

\section{Reference.}

FWI/GFW. 2001. Keadaan Hutan Indonesia. Bogor, Indonesia: Forest Watch Indonesia, http://unfcc.int

Indonesian Environment Ministry, 2005, Database of National ISO 14.000 Certification, Jakarta, Indonesia, http://faostat.fao.org.

Ikezuki, T, 2009, Trade and Climate Change, Paris

Li Aixian, 1999, Energy Conservation and Energy Conservation Standardization in China, www.iso.org.

Mark T. Petruzzi, 2003, Ecolabeling, Environmental Standards, and Certification

Samuel J. Ochieng, 2006, Climate Change and the $\mathrm{C}$, hallenges for the Consumer Movement, www.iso.org.

Zakiyah. 2009. Pola Penyebaran Lembaga Sertifikasi di Bawah Skema KAN. National Acreditation Committee. 